Paedagogia Christiana

I/27 (20I I) - ISSN 1505-6872

Ewelina Świdrak ${ }^{*}$

Lublin

\title{
Wczoraj i dziś pedagogiki uniwersyteckiej w świetle życia i twórczości Stefana Kunowskiego, Lublin, 15 grudnia 2009 roku
}

Dnia 15 grudnia 2009 roku odbyła się konferencja naukowa Wczoraj i dziś pedagogiki uniwersyteckiej w świetle życia i twórczości Stefana Kunowskiego, zorganizowana przez Katedrę Pedagogiki Chrześcijańskiej Instytutu Pedagogiki Katolickiego Uniwersytetu Lubelskiego Jana Pawła II. Patronat nad konferencją objęli Jego Magnificencja Rektor KUL ks. prof. dr hab. Stanisław Wilk oraz Dziekan Wydziału Nauk Społecznych KUL prof. dr hab. Andrzej Sękowski. Celem konferencji było uczczenie pamięci wybitnego pedagoga, nauczyciela akademickiego KUL, profesora Stefana Kunowskiego, w setną rocznicę jego urodzin oraz podjęcie refleksji nad kształtem i jakością pedagogiki uniwersyteckiej.

Konferencja odbyła się w Kampusie Akademickim Katolickiego Uniwersytetu Lubelskiego Jana Pawła II, ul. Droga Męczenników Majdanka 70 w Lublinie. Obrady konferencji zostały podzielone na dwie zasadnicze części: obrady plenarne, które odbyły się w auli im. Stefana Kunowskiego, i dyskusje panelowe w pięciu grupach. Ogólnie w konferencji wzięło udział ponad 50 prelegentów.

O godzinei 9.00 uroczystego otwarcia konferencji dokonał Prorektor ds. Dydaktyki i Wychowania KUL, prof. dr hab. Józef Franciszek Fert

* Dr Ewelina Milena Świdrak, asystent w Katedrze Psychopedagogiki Instytutu Pedagogiki Katolickiego Uniwersytetu Lubelskiego Jana Pawła II. Autorka posłużyła się cząstkowymi sprawozdaniami z pracy grup dyskusyjnych, które przygotowali: Grupa I - dr hab. Ryszard Skrzyniarz; Grupa II - mgr Ewelina Świdrak; Grupa III - dr Magdalena Parzyszek; Grupa IV - mgr Elżbieta Jasińska; Grupa V - dr Piotr Magier. 
i Dziekan Nauk Społecznych, prof. dr hab. Andrzej Sękowski, zaproszonych gości i uczestników konferencji powitała również prof. dr hab. Alina Rynio - Dyrektor Instytutu Pedagogiki KUL.

O godzinie 9.30 rozpoczęła się sesja plenarna, której przewodniczyli prof. dr hab. M. Chodkowska, ks. prof. dr hab. A. Dębiński oraz dr M. Rembierz. Jako pierwsza wystapiła prof. dr hab. Alina Rynio z prelekcją Pedagogika uniwersytecka w życiu i twórczości Profesora Stefana Kunowskiego. Prelegentka przedstawiła sylwetkę prof. Kunowskiego i jego wkład do pedagogiki naukowej. W trudnych czasach komunizmu prof. Kunowski oparł swoją koncepcję pedagogiki na chrześcijańskiej koncepcji człowieka. Powołał również do istnienia pedagogikę katolicką jako subdyscyplinę pedagogiczną. Prof. A. Rynio, opisując życie uczelniane prof. Kunowskiego, podkreślała między innymi, że był zawsze wzorem do naśladowania dla swoich studentów. Znaczną część swojego wystąpienia Pani Profesor poświęciła metodom i środkom wychowania, jakie preferował Stefan Kunowski.

Drugi z prelegentów, ks. prof. dr hab. Marian Nowak, przedstawił temat Wczoraj i dziś pedagogiki uniwersyteckiej. Ksiądz Profesor, opisując historię pedagogiki uniwersyteckiej w Katolickim Uniwersytecie Lubelskim, podkreślał, że dzięki swojej niezależności miała zawsze szczególny status. Charakteryzując zaś współczesny charakter pedagogiki naukowej, opisywał jej multidyscyplinarność, interdyscyplinarność i transdyscyplinarność.

Jako trzeci wystąił dr Marek Rembierz, który podjął temat: Pedagogika uniwersytecka $w$ kontekście misji uniwersytetu. Mówił o swoistości i nieredukowalności misji uniwersytetu, a także o specyfice uniwersytetu katolickiego. Według niego, problemem współczesnych uniwersytetów jest obniżanie jakości kształcenia poprzez przystosowanie się do poziomu coraz większej rzeszy młodych ludzi, którzy chcą się kształcić na uczelniach wyższych. Podkreślał również, że funkcja dydaktyczna uniwersytetu jest drugorzędna, „,elem zaś uniwersytetu jest to, aby człowiek nauczył się myśleć”.

Po przerwie, o godzinie 11.30, uczestnicy konferencji udali się do wcześniej wyznaczonych sal, tworząc grupy dyskusyjne, w ramach których podjęli pracę dotyczącą następujących problemów: Grupa I - Dawne i wspótczesne sylwetki uniwersyteckich pracowników naukowo-dydaktycznych; Grupa II - Młodzież akademicka wczoraj i dziś; Grupa III - Organizacja pracy na uniwersytecie i problematyka uniwersytetów katolickich; Grupa IV - Wybrane zagadnienia kształcenia przyszłych pedagogów; Grupa V - Aktualne wyzwania stojace przed dydaktyka uniwersyteckq.

W grupie I prowadzącymi byli: dr hab. Ryszard Skrzyniarz oraz dr Ewa Smołka. Referenci zaprezentowali następujące tematy: prof. dr hab. G. Karolewicz: Nauczyciele akademiccy dwudziestolecia międzywojennego, ks. prof. dr hab. E. Walewander: Pedagogia uniwersytetu w życiu i działalności Zyg- 
munta Kukulskiego (1890-1944), mgr M. Tomczyk: Autorytet nauczyciela akademickiego w twórczości o. Jacka Woronieckiego, dr hab. R. Skrzyniarz: Wybrane przykłady postaw i działań ukierunkowanych na przetrwanie oraz rozwój Katolickiego Uniwersytetu Lubelskiego w latach 1944-1970, dr B. Kiereś: Troska o integralne wychowanie w ujęciu dominikańskich mistrzów kształcenia uniwersyteckiego, dr M. Rembierz: Aktualność klasycznej pedagogiki uniwersyteckiej Stefana Swieżawskiego, dr D. Opozda: Pedagogika rodziny w uniwersyteckiej działalności Księdza Profesora Józefa Wilka, dr A. Szudra: Wojciecha Chudego pedagogia godności, dr E. Smołka: Pedagogiczne przesłania prof. Teresy Kukołowicz, ks. mgr D. Bondyra: J. Ratzinger jako uczony $i$ wykładowca. Prelegenci prezentowali sylwetki rektorów KUL i nauczycieli akademickich, którzy byli nie tylko znakomitymi naukowcami, ale i dobrymi, życzliwymi ludźmi, wspaniałymi wychowawcami, a tym samym wzorami dla swoich studentów. Byli to retorzy: ks. Idzi Radziszewski, o. Jacek Woroniecki, Antoni Szymański, ks. Antoni Słomkowski, ks. Marian Rechowicz, ks. Józef Iwanicki, ks. Wincenty Granat, o. Albert Krapiec oraz profesorowie: Zygmunt Kukulski, Feliks Bednarski, Stefan Swieżawski. Wśród znaczących dla społeczności akademickiej profesorów znaleźli się również ci bezpośrednio związani z Pedagogiką w KUL - Stefan Kunowski, Józef Wilk, Wojciech Chudy, Teresa Kukołowicz. W grupie pierwszej mówiono także o trudnej sytuacji uniwersytetu, w jakiej znalazł się on po drugiej wojnie światowej, w tym o trudnościach lokalowych (budynek uniwersytetu był zrujnowany po wojnie) czy problemach studentów (ich niedożywieniu i ogólniej biedzie).

Przedmiotem dyskusji w grupie drugiej była młodzież akademicka. Prowadzącymi obrady byli: dr Joanna Karczewska oraz o. dr Krzysztof Bieliński. W grupie zaprezentowano następujące referaty: prof. dr hab. P. P. Gach: Formacja w Stowarzyszeniu Młodzieży Akademickiej „,Odrodzenie” w okresie międzywojennym, dr J. Karczewska: Cele i zadania chrześcijańskiego wychowania młodzieży w twórczości Stefana Kunowskiego, prof. dr hab. M. Chodkowska: Postawy studentów wobec wartości moralnych a medialny wizerunek wyższych uczelni, mgr S. Konefał: Stużebna rola pedagogiki uniwersyteckiej $w$ nauczaniu wychowujacym współczesnej młodzieży akademickiej, o. dr K. Bieliński: Oczekiwania i aspiracje młodzieży akademickiej WSKSiM, dr A. Lendzion: Credo zawodowe przyszłych pedagogów, mgr K. Braun: Społeczne uczestnictwo studentów KUL Jana Pawła II na przykładzie wolontariatu studenckiego. Zagadnieniami, które wzbudziły największe zainteresowanie w grupie były kwestie dotyczące wychowania moralnego i kształtowania cech osobowości studentów uczelni katolickich, roli prawidłowych, osobowych relacji międzyludzkich w formacji studentów, roli wolontariatu w życiu młodzieży akademickiej. Na szczególną uwagę za- 
sługuje oprawiona w barwną szatę wizualną prezentacja dr J. Karczewskiej, która opisując sylwetkę profesora Kunowskiego wyświetlała jego zdjęcia.

Temat, nad którym pracowano w trzeciej grupie dyskusyjnej, brzmiał: Organizacja pracy na uniwersytecie i problematyka uniwersytetów katolickich. Obradom tej grupy przewodniczyli: dr Ewa Domagała-Zyśk oraz dr hab. Grzegorz Grzybek. Tematy referatów grupy trzeciej przedstawiają się następująco: dr W. Perdeus, doc. UMCS: Nowy model zarzadzania szkolnictwem wyższym i nowy model kariery akademickiej, prof. dr hab. G. Nowak: Plusy i minusy realizacji procesu bolońskiego, dr E. Domagała-Zyśk: Wczoraj $i$ dziś międzynarodowej wymiany doświadczeń akademickich, ks. dr hab. A. Maj: Nauczyciel akademicki w uniwersytecie jako organizacji zarzqdzajqcej jakościq, ks. prof. dr hab. A. Dębiński: Spoteczna misja uniwersytetów katolickich, dr M. Parzyszek: Katolicki Uniwersytet Lubelski w postudze Prymasa Tysiqclecia, prof. dr hab. A. Rynio: Misja Katolickiego Uniwersytetu Lubelskiego w perspektywie przestania Jana Pawła II. Ważnymi wnioskami z pracy w trzeciej grupie było sformułowanie zagrożeń edukacji w uniwersytetach katolickich. Są to między innymi: zurzędniczenie statusu nauczyciela akademickiego, obniżenie poziomu intelektualnego absolwentów, uzawodowienie studiów i dehumanizacja, brak znajomości misji uniwersytetów katolickich, brak świadomości przynależności do rodziny, narodu i państwa.

Czwarta grupa dyskusyjna, której obradom przewodniczył ks. dr Andrzej Łuczyński, podjęła temat: Wybrane zagadnienia kształcenia przyszłych pedagogów. Przedstawiono w niej osiem referatów. Grupę osób referujących stanowiły osoby związane z Katolickim Uniwersytetem Lubelskim Jana Pawła II. Tematy referatów przedstawiają się następująco: ks. dr A. Łuczyński: Rozwój i ocena pracowników naukowo-dydaktycznych w perspektywie awansu zawodowego, mgr U. Czyżewska: Permanentna autoedukacja pracowników naukowych $i$ studentów wyzwaniem dla wymagań społeczeństwa wiedzy, mgr H. Nowak: Struktura wartości w ksztatceniu przyszlych pedagogów, mgr S. Grabczan: Dialog w akademickim procesie kształcenia przysztych nauczycieli, mgr E. Kuna: Metoda projektów w kształceniu akademickim $w$ aspekcie twórczej postawy studenta, mgr M. Religa: Podmiotowość w kształceniu pedagogów i nauczycieli, mgr M. Dawidowicz, mgr A. Sobaszek: Twórczy nauczyciel akademicki - z perspektywy doświadczeń absolwentów KUL, mgr E. Jasińska: Pytanie o tożsamość współczesnego pedagoga i nauczyciela. Jednym z zagadnień przedstawionych podczas dyskusji był profil pracownika naukowo-dydaktycznego oraz konieczność doskonalenia osobowości, poszukiwania własnej tożsamości oraz doskonalenia zawodowego jako komponentów rozwoju pracowników naukowo-dydaktycznych. Omówiona została także reforma systemu oświaty jako czynnik koncepcji 
zmian kształcenia nauczycieli edukacji elementarnej. Innym ważnym zagadnieniem omówionym w grupie IV były wartości, wokół których zorganizowane ma być kształcenie przyszłych pedagogów. Są to podmiotowość oraz kategoria samowychowania jako najważniejszy element dochodzenia do podmiotowości, a także twórcza aktywność i mistrzostwo nauczyciela akademickiego.

Tytuł organizujący wystapienia uczestników V grupy brzmiał: Aktualne problemy stojqce przed dydaktykq uniwersyteckq. Obradom w grupie V przewodniczyli: dr Dorota Bis oraz dr Piotr Magier. W grupie zaprezentowano dziesięć referatów, które wygłosili: prof. dr hab. K. Chałas: Struktury treści dydaktycznych $w$ procesie kształcenia pedagogów $w$ świetle warstwicowej teorii rozwoju człowieka Stefana Kunowskiego; prof. dr hab. W. Wójcik: Współczesne wyzwania pedagogiki uniwersyteckiej - między naukami ścistymi i naukami humanistycznymi; dr P. Magier: Ksztatcenie uniwersyteckie jako przedmiot dyskusji w pedagogice; dr M. Łobacz: Postulat kształcenia pedagogicznego dostrzegajacego wartość każdej osoby ludzkiej; dr M. Rembierz: Elementy współczesnej dydaktyki uniwersyteckiej - w kręu analiz i postulatów Leona Koja; dr D. Bis: Dydaktyka uniwersytecka w kontekście wyzwań cybernetycznego społeczeństwa; mgr K. Gromek oraz mgr M. BukCegiełka: Posiadane kompetencje pedagoga szkolnego i ich brak $w$ zderzeniu z praktyka; mgr K. Ożóg: Szkolnictwo wyższe w Stalowej Woli wobec wyzwań rynku pracy; dr B. Jakimiuk: Europejskie Ramy Kwalifikacji narzędziem uczenia się przez całe życie; mgr M. Kapuścińska: Z tradycja w przyszłość. Kształcenie u przyszłych nauczycieli umiejętności myślenia kategoriami przyszłości. Tematykę prezentowanych wystapień sprowadzić można do następujących zakresów tematycznych: 1) aplikacja wybranych kategorii koncepcji pedagogicznych i filozoficznych do strukturalizacji treści oraz metod nauczania i wychowania stosowanych w edukacji uniwersyteckiej; 2) współczesny, społeczno-kulturowy kontekst procesu edukacji uniwersyteckiej; 3) analiza i typologizacja koncepcji kształcenia uniwersyteckiego według kategorii historycznych i merytorycznych; 3) analiza modelu kształcenia pozauniwersyteckiego. Wystapienia wchodzące w pierwszy zakres tematyczny, stanowiły próbę odpowiedzi na pytanie dotyczące fundamentalnych kategorii organizujących proces kształcenia uniwersyteckiego. Wychodząc od koncepcji personalizmu, stanowiska S. Kunowskiego oraz L. Koja, autorzy scharakteryzowali elementy struktury zaproponowanego przez siebie modelu edukacji uniwersyteckiej, opierającego się na kategoriach: godności, wolności, rozumności, podmiotowości - przynależnych człowiekowi z racji jego osobowej natury; fazach rozwoju osobowości człowieka - biologicznej, psychicznej, społecznej, kulturowej, duchowej; moralnych postulatach: rzetelności, konsekwencji, odpowiedzialności. Wystapienia drugiego bloku te- 
matycznego ogniskowały się na współczesnych procesach społeczno-kulturowych, jako kontekście warunkującym treści i sposób prowadzenia edukacji uniwersyteckiej. Autorzy zwrócili uwagę między innymi na konsekwencje wynikające $\mathrm{z}$ wprowadzenia technik informatycznych w proces kształcenia uniwersyteckiego, a także nie zawsze spełnionych przez uniwersytet oczekiwań płynących ze strony rynku pracy. Treści wystąpień autorów trzeciego bloku tematycznego zawierały próbę typologicznego uporządkowania modeli kształcenia uniwersyteckiego. Były to: starożytny, średniowieczny, oświeceniowy, współczesny model uniwersytetu oraz klasyczny (humanistyczny) i pragmatyczny model kształcenia uniwersyteckiego. Za odrębne treściowo uznać można wystapienie dr B. Jakimiuk, dotyczące pozaformalnego systemu nabywania kwalifikacji zawodowych oraz ewaluacji kształcenia uniwersyteckiego w ramach Unii Europejskiej funkcjonującego pod nazwą: Europejskich Ram Kwalifikacji. Autorka określiła naczelne postulaty wspomnianego Projektu skupione wokół zasad: wielości ścieżek nabywania kompetencji; efektywności kształcenia przeciwstawionego zasadzie stopni formalnych; porównywalności jakości dyplomów w ramach Unii Europejskiej. Autorka wskazała także na znaczenie edukacyjne Europejskich Ram Kwalifikacji w kontekście edukacji dorosłych oraz scharakteryzowała prawne procedury dostosowania praw państw Unii do jego realizacji.

Około godziny 15.30, po odczytaniu sprawozdań z pracy grup dyskusyjnych, podsumowania konferencji dokonali ks. prof. dr hab. M. Nowak i prof. dr hab. A. Rynio. Jeszcze raz przywołano postać profesora Stefana Kunowskiego, podkreślając jego zasługi dla pedagogiki jako nauki. Zauważono jednocześnie, że jego spuścizna nie jest jeszcze w całości opisana, co stanowi wyzwanie dla naszego środowiska naukowego. Pani Profesor Alina Rynio powiedziała: „Przenieśliśmy do tego budynku i do naszych serc pamięć o profesorze Stefanie Kunowskim. Nasza konferencja miała temu służyć. Nasza pamięć będzie trwać, po to, aby on żył”. 